\title{
Pengaruh Model Project Based Learning Berbantuan Media Animasi terhadap Kompetensi Pengetahuan IPS
}

\author{
Ni Nym. Sri Arianti1* ${ }^{*}$ I Kt. Adnyana Putra², I Wyn. Sujana ${ }^{3}$ \\ 1 Jurusan Pendidikan Guru Sekolah Dasar,Universitas Pendidikan Ganesha Singaraja \\ 2 Jurusan Pendidikan Guru Sekolah Dasar,Universitas Pendidikan Ganesha Singaraja \\ ${ }^{3}$ Jurusan Pendidikan Guru Sekolah Dasar,Universitas Pendidikan Ganesha Singaraja
}

\begin{abstract}
Abstrak
Penelitian ini bertujuan untuk mengetahui pengaruh model Project Based Learning berbantuan media animasi terhadap kompetensi pengetahuan IPS siswa kelas V SD Gugus 5 Mengwi tahun pelajaran 2017/2018. Penelitian ini merupakan jenis penelitian eksperimen semu (quasi experiment) dengan rancangan nonequivalent control group design. Populasi penelitian ini adalah seluruh siswa kelas V SD Negeri di Gugus 5 Mengwi tahun pelajaran 2017/2018 yang berjumlah 234 orang siswa. Sampel ditentukan dengan menggunakan teknik random sampling. Sampel dalam penelitian ini adalah siswa kelas V SD No. 3 Buduk dengan jumlah 42 orang siswa sebagai kelompok eksperimen dan siswa kelas V SD No. 1 Abianbase dengan jumlah 37 orang siswa sebagai kelompok kontrol. Pengumpulan data dilakukan dengan menggunakan metode tes dengan bentuk tes objektif pilihan ganda biasa. Data yang diperoleh dianalisis menggunakan uji-t. Hasil analisis data diperoleh thitung $=6,146$ sedangkan pada taraf signifikansi $5 \%$ dan $\mathrm{dk}=77$ diperoleh nilai ttabel $=2,000$ sehingga thitung $>$ ttabel $(6,146>2,000)$. Berdasarkan kriteria pengujian, maka HO yang berbunyi tidak terdapat perbedaan yang signifikan kompetensi pengetahuan IPS antara kelompok siswa yang dibelajarkan dengan model Project Based Learning berbantuan media animasi dengan kelompok siswa yang dibelajarkan dengan model pembelajaran konvensional pada siswa kelas V SD Gugus 5 Mengwi Tahun Pelajaran 2017/2018 ditolak dan Ha diterima . Adapun nilai rata -rata kompetensi pengetahuan IPS siswa kelompok eksperimen adalah $X^{-}=82,24$, sedangkan kelompok kontrol adalah $X^{-}=72,53$. Berdasarkan hasil penelitian tersebut dapat disimpulkan bahwa terdapat pengaruh model Project Based Learning berbantuan media animasi terhadap kompetensi pengetahuan IPS siswa kelas V SD Gugus 5 Mengwi tahun pelajaran 2017/2018.

\author{
Keywords: \\ kompetensi \\ pengetahuan IPS, \\ media animasi, Project
}

Based Learning,
\end{abstract}

\section{PENDAHULUAN}

Kurikulum memegang peranan penting dalam proses pembelajaran. Kurikulum yang diterapkan akan menjadi pedoman dalam pelaksaaan pembelajaran. Dalam Undang-undang Nomor 20 Tahun 2003 tentang Sistem Pendidikan Nasional disebutkan bahwa kurikulum adalah seperangkat rencana dan pengaturan mengenai tujuan, isi, dan bahan pelajaran serta cara yang digunakan sebagai pedoman penyelenggaraan kegiatan pembelajaran untuk mencapai tujuan pendidikan tertentu. Peranan kurikulum di sekolah sangatlah strategis dan menentukan bagi tercapainya tujuan pendidikan. Untuk mencapai tujuan pendidikan tersebut berbagai upaya telah dilakukan pemerintah salah satunya dengan melakukan pengembangan terhadap kurikulum pendidikan di Indonesia.

Kurikulum yang diterapkan saat ini adalah Kurikulum 2013 yang merupakan penyempurnaan dari kurikulum KTSP. Pengembangan kurikulum KTSP menjadi Kurikulum 2013 bertujuan untuk mempersiapkan manusia Indonesia agar memiliki kemampuan hidup sebagai pribadi dan warga negara yang beriman, produktif, kreatif, inovatif, dan afektif serta mampu berkontribusi pada kehidupan bermasyarakat, berbangsa, bernegara, dan peradaban dunia (Daryanto, dkk., 2014). Kurikulum 2013 merupakan salah satu indikator yang menentukan berhasil tidaknya suatu pendidikan, oleh karena itu kurikulum harus dikelola secara baik dan profesional dan diimplementasikan dengan baik dalam proses pembelajaran. 
Penerapan Kurikulum 2013 sudah secara bertahap dilaksanakan di Bali, khususnya di Kabupaten Badung. Hal ini sesuai dengan kebijakan pemerintah yang tercantum dalam pasal 1 Ayat 1 Permendikbud Nomor 57 Tahun 2014 yang menyatakan bahwa kurikulum pada Sekolah Dasar/Madrasah Ibtidaiyah yang telah dilaksanakan sejak tahun 2013/2014 disebut Kurikulum 2013 Sekolah Dasar/Madrasah Ibtidaiyah. Sejalan dengan hal tersebut, dalam Permendikbud Nomor 24 Tahun 2016 disebutkan pelaksanaan pembelajaran Kurikulum 2013 pada Sekolah Dasar/Madrasah Ibtidaiyah (SD/MI) dilakukan dengan pendekatan pembelajaran tematik terpadu, kecuali untuk mata pelajaran Matematika, dan Pendidikan Jasmani Olahraga dan Kesehatan (PJOK) sebagai mata pelajaran yang berdiri sendiri untuk kelas IV, V, dan VI.

Pembelajaran tematik terpadu merupakan pendekatan pembelajaran yang mengintegrasikan berbagai kompetensi dari berbagai mata pelajaran ke dalam suatu tema. Sejalan dengan pendapat tersebut, Susanto (2014:289) menyatakan "pembelajaran terpadu adalah upaya memadukan berbagai materi belajar yang berkaitan, baik dalam satu disiplin ilmu maupun antar disiplin ilmu dengan kehidupan dan kebutuhan nyata para siswa, sehingga proses belajar anak menjadi sesuatu yang bermakna dan menyenangkan anak". Pengalaman belajar tersebut akan dapat memudahkan siswa memahami materi yang dibelajarkan karena dilaksanakan dengan berpedoman pada pengalaman yang telah dimiliki siswa dan lingkungan sekitar sebagai sumber belajar. Dengan pendekatan tematik terpadu diharapkan pembelajaran akan dapat terlaksana sesuai penjelasan dalam Permendikbud Nomor 22 Tahun 2016 yang menyatakan proses pembelajaran pada satuan pendidikan diselenggarakan dengan interaktif dan inspiratif, menyenangkan, menantang, dan memotivasi peserta didik untuk berpartisipasi aktif, kontekstual dan kolaboratif, dapat memberikan ruang yang cukup bagi prakarsa, kreativitas, dan kemandirian peserta didik, serta sesuai dengan bakat, minat, kemampuan dan perkembangan fisik maupun psikologis peserta didik.

Berbagai harapan dan tujuan dari penerapan Kurikulum 2013 tersebut pada kenyataannya belum mampu tercapai secara optimal. Hal tersebut disebabkan karena penerapan Kurikulum 2013 cukup banyak mengalami kendala, khususnya ketika guru melaksanakan pembelajaran secara terpadu. Wahidmurni (2017), menunjukkan prioritas permasalahan yang dihadapi guru dalam melaksanakan pembelajaran terpadu, khususnya pada mata pelajaran Ilmu Pengetahuan Sosial (IPS) meliputi kurangnya pemahaman tentang cara mengembangkan materi IPS secara terpadu, kurangnya pemahaman tentang konsep pembelajaran IPS terpadu, kemampuan untuk menerapkan metode pembelajaran, dan kemampuan dalam melaksanakan penilaian pembelajaran, serta kurangnya kemampuan siswa dalam menyampaikan pendapat.

Berdasarkan hasil observasi di SD Gugus 5 Mengwi pada hari Rabu, 8 Januari 2018, diperoleh informasi bahwa guru masih kesulitan dalam menerapkan Kurikulum 2013. Guru masih belum bisa berpindah dari pembelajaran dalam Kurikulum KTSP dan menerapkan pembelajaran saintifik dalam Kurikulum 2013. Fokus pada perubahan kurikulum tersebut mengakibatkan guru melupakan strategi belajar seperti penerapan model dan penggunaan media dalam pembelajaran, sehingga pembelajaran menjadi kurang bervariasi dan memotivasi siswa. Hal tersebut mengakibatkan penyerapan materi pelajaran oleh siswa masih belum optimal sehingga berimbas pada hasil belajarnya, terutama hasil belajar IPS. Dari data salah satu SD di Gugus 5 Mengwi, rata-rata pencapaian kompetensi pengetahuan IPS siswa kelas $\mathrm{V}$ hanya 77,32 dan rata-rata tersebut paling rendah dibandingan rata-rata pencapaian mata pelajaran lainnya seperti PPKn, Bahasa Indonesia, Matematika, dan IPA. Data tersebut tentunya merupakan sebuah permasalahan tambahan dalam pelaksanaan Kurikulum 2013 selain permasalahan yang telah di ungkapkan oleh Wahidmurni di atas, dan juga menjadi permasalahan bagi mata pelajaran IPS itu sendiri yang pada hakekatnya merupakan mata pelajaran dasar dari seluruh jenjang pendidikan sekolah (Gunawan, 2016).

IPS sebagai suatu ilmu, menaungi berbagai jenis ilmu sosial lain yang mencakup kajian berbagai aspek kehidupan yang majemuk baik hubungan sosial, ekonomi, psikologi, budaya, sejarah, maupun politik. IPS merupakan suatu program pendidikan yang mengintegrasikan konsep-konsep ilmu sosial dan humaniora untuk tujuan pendidikan (Lasmawan, 2010). Pendidikan IPS dikembangkan dalam rangka meningkatkan kualitas sumber daya manusia di bidang sikap, pengetahuan, serta keterampilan yang berpijak pada kehidupan masyarakat secara umum. Di dalam pembelajaran IPS sesuai pedoman Kurikulum 2013 yang dijelaskan dalam Permendikbud Nomor 24 Tahun 2016, sikap, pengetahuan, dan keterampilan tersebut dikategorikan sebagai tingkat kemampuan untuk mencapai standar kompetensi lulusan yang harus dimiliki oleh siswa yang diistilahkan sebagai kompetensi inti yang terdiri atas kompetensi inti sikap spiritual, kompetensi inti sikap sosial, kompetensi inti pengetahuan, dan kompetensi inti keterampilan.

Permasalahan belum optimalnya nilai penguasaan kompetensi pengetahuan siswa terhadap materi mata pelajaran IPS seperti yang dipaparkan di atas dapat disebabkan karena ada suatu pemahaman yang 
salah dengan menyatakan IPS sebagai pelajaran yang cenderung hafalan (Wahidmurni, 2017), sehingga IPS masih sering dibelajarkan dengan menerapkan metode pembelajaran yang lebih menekankan pada keaktifan guru, bukan keaktifan siswa dan pemberian tes yang memerlukan jawaban bersifat hafalan atau mengulang kembali informasi yang telah dipelajari sebelumnya tanpa memberikan kesempatan kepada siswa untuk dapat berpikir dan mengembangkan gagasannya secara lebih mendalam terhadap permasalahan yang disajikan, sehingga akibatnya siswa akan kesulitan untuk mengembangkan berbagai potensi yang dimilikinya.

Usaha dalam mengembangkan potensi siswa perlu dilakukan dengan menerapkan sebuah model pembelajaran inovatif dan konstruktif yang nantinya akan dapat meningkatkan kemampuan siswa dalam memahami materi pelajaran. Salah satu cara untuk mewujudkannya adalah dengan menerapkan model pembelajaran yang sesuai dengan paradigma baru pendidikan, pembelajaran yang dapat meningkatkan keaktifan siswa dalam proses pembelajaran dan memaksimalkan interaksi antara komponen pembelajaran. Sebagai seorang guru harus mampu menyesuaikan diri terhadap karakteristik dan sikap dasar siswa sehingga mampu membawa siswa ke dunia yang dikehendaki berdasarkan tujuan pembelajaran. Dengan penerapan seperti di atas, ikatan emosi, empati, dan saling ketergantungan antara siswa dan guru terjadi dan memunculkan dimensi keberhasilan belajar.

Sebagai salah satu alternatif untuk mengatasi kelemahan-kelemahan yang dihadapi oleh guru dalam proses pembelajaran, maka diterapkan model pembelajaran untuk mengoptimalkan proses pembelajaran terhadap kompetensi pengetahuan IPS siswa, yakni model Project Based Learning. Menurut Al-Tabany (2015:42) "Project Based Learning merupakan model pembelajaran inovatif yang berpusat pada siswa (student center) dan menempatkan guru sebagai motivator dan fasilitator, dimana siswa diberi peluang bekerja secara otonom mengkonstruksi belajarnya". Pembelajaran melalui model Project Based Learning ini dapat diterapkan sebagai sebuah model belajar untuk mengembangkan kemampuan siswa dalam membuat perencanaan, berkomunikasi, menyelesaikan masalah, dan membuat keputusan.

Adapun kelebihan model Project Based Learning, yaitu 1) meningkatkan motivasi siswa untuk belajar dan mendorong mereka untuk melakukan pekerjaan penting, 2) meningkatkan kemampuan siswa untuk menyelesaikan masalah, 3) membuat siswa menjadi lebih aktif dalam menyelesaikan masalah yang kompleks, 4) meningkatkan kemampuan siswa dalam bekerja sama, 5) mendorong siswa untuk mempraktikkan keterampilan berkomunikasi yang baik, 6) meningkatkan keterampilan siswa dalam mengelola sumber belajar, 7) memberikan pengalaman kepada siswa dalam mengorganisasi proyek, mengalokasi waktu, dan mengelola sumber daya seperti peralatan dan bahan untuk menyelesaikan tugas, 8) memberikan kesempatan belajar bagi siswa untuk berkembang sesuai kondisi dunia nyata, 9) melibatkan siswa untuk belajar mengumpulkan informasi dan menerapkan pengetahuan tersebut untuk menyelesaikan permasalahan di dunia nyata, dan 10) membuat suasana belajar menjadi lebih menyenangkan.

Selain menerapkan model pembelajaran yang tepat, guru juga memerlukan media pembelajaran yang dapat membantu pemahaman siswa dalam menyerap materi pelajaran. Siswa akan lebih mengerti dan paham jika guru dalam pembelajaran menggunakan benda konkret/animasi menyerupai suasana sebenarnya.

Menurut Arsyad (2017:10) "media pembelajaran adalah segala sesuatu yang dapat digunakan untuk menyampaikan pesan atau informasi dalam proses belajar mengajar sehingga dapat merangsang perhatian dan minat siswa dalam belajar". Dengan memanfaatkan media pembelajaran dalam proses pembelajaran akan dapat lebih menarik perhatian siswa sehingga dapat menumbuhkan motivasi belajar. Materi pelajaran akan lebih jelas maknanya sehingga dapat lebih dipahami oleh siswa.

Untuk mendukung penerapan model Project Based Learning maka salah satu media yang dapat digunakan adalah media animasi. Animasi adalah gambar yang dibuat dengan menggunakan teknik tertentu sehingga gambar tersebut menjadi seakan bergerak apabila dilihat oleh mata (Aditya, 2014). Penggunaan animasi dalam pembelajaran akan dapat membuat pembelajaran lebih bermakna. Susanto (2014) secara lebih khusus menjelaskan kelebihan penggunaan media animasi dalam pembelajaran, yaitu 1) menghilangkan hambatan intelektual untuk belajar, 2) dapat membantu mengatasi hambatan fisik tertentu pada siswa, 3) menghadirkan berbagai peristiwa dalam kontinuitas untuk memberikan pengalaman visual khusus dalam rangka pemahaman yang lebih mendalam, 4) memungkinkan siswa untuk menciptakan tindakan nyata atau membayangkan suatu kejadian atau proses, dan 5) berguna untuk mengevaluasi pengetahuan siswa atau kemampuan analisis mereka dalam pembelajaran materi tertentu.

Penelitian ini dilaksanakan di SD Gugus 5 Mengwi, Kabupaten Badung dengan tujuan untuk mengetahui pengaruh model Project Based Learning berbantuan media animasi terhadap penguasaan kompetensi pengetahuan IPS siswa kelas V SD Gugus 5 Mengwi tahun pelajaran 2017/2018. 


\section{METODE PENELITIAN}

Penelitian ini merupakan jenis penelitian kuantitatif dengan rancangan eksperimen semu (quasi experiment). Rancangan ini mempunyai kelompok kontrol, tetapi tidak dapat berfungsi sepenuhnya untuk mengontrol variabel-variabel luar yang mempengaruhi pelaksanaan eksperimen (Sugiyono, 2009). Desain eksperimen yang digunakan dalam penelitian ini adalah Nonequivalent Control Group Design. Dalam desain ini, ada dua kelompok yang satu mendapat perlakukan dan satu kelompok sebagai kelompok kontrol. Kedua kelompok memperoleh pretest dan posttest. Pretest diberikan kepada kelompok kontrol dan kelompok eksperimen. Pemberitan pretest ini digunakan untuk mengetahui apakah sampel yang terpilih sudah setara atau tidak. Sejalan dengan hal tersebut, Dantes (2012:97) menyatakan "pemberian pretest biasanya digunakan untuk mengukur equivalensi atau penyetaraan kelompok". Setelah diberikan pretest peneliti memberikan perlakuan dalam pembelajaran, yaitu memberikan perlakuan dengan model Project Based Learning berbantuan media animasi kepada kelompok eksperimen sedangkan kelompok kontrol dibelajarkan dengan pembelajaran konvensional. Kemudian setelah diberikan perlakuan, dilakukan posttest untuk mengetahui kompetensi pengetahuan IPS siswa.

Populasi penelitian ini adalah seluruh siswa kelas V SD Negeri di Gugus 5 Mengwi tahun pelajaran 2017/2018 yang berjumlah 234 orang siswa. Penentuan sampel pada penelitian ini menggunakan teknik sampling untuk menentukan sampel yang akan digunakan. Teknik sampling yang digunakan dalam penelitian ini adalah random sampling (sampel acak). "Dalam teknik ini setiap individu memiliki peluang atau kesempatan yang sama untuk dijadikan subjek penelitian" (Setyosari, 2015:223). Untuk menentukan sampel, cara yang digunakan adalah dengan cara mengundi kelas yang ada dalam populasi. Setelah dilakukan pengundian, diperoleh sampel yang menjadi kelompok eksperimen adalah kelas V SD No. 3 Buduk dengan jumlah 42 orang siswa dan kelas V SD No. 1 Abianbase dengan jumlah 37 orang siswa menjadi kelompok kontrol.

Pengumpulan data dalam penelitian ini menggunakan metode tes. Data yang dikumpulkan dalam penelitian ini adalah data tes kompetensi pengetahuan IPS siswa. Tes yang digunakan untuk mengukur kompetensi pengetahuan IPS siswa berupa tes objektif dalam bentuk pilihan ganda biasa. Tes pilihan ganda biasa ini meliputi 4 pilihan jawaban ( $a, b, c$ atau d). Setiap item diberikan skor 1 bila siswa menjawab dengan benar dan skor 0 bila siswa menjawab salah. Skor setiap jawaban dijumlahkan dan dibagi dengan jumlah soal seluruhnya, sehingga jumlah tersebut menjadi nilai untuk semua item yang membangun soal kompetensi pengetahuan IPS yang bergerak dari kisaran 0-100. 0 merupakan nilai minimal dan 100 merupakan nilai maksimal tes kompetensi pengetahuan IPS siswa.

Sebelum tes diberikan kepada sampel, tes tersebut terlebih dahulu divalidasi secara teoretis dengan menggunakan kisi-kisi dan dikonsultasikan pada ahli, selanjutnya dilakukan validasi secara empirik dengan jumlah responden sebanyak 34 orang siswa. Dari hasil uji instrumen yang meliputi uji validitas, uji daya beda, uji tingkat kesukaran, dan uji reliabilitas diperoleh 30 butir tes yang dinyatakan layak digunakan dalam penelitian dari total 50 butir tes yang diujicobakan.

Analisis data dalam penelitian ini meliputi analisis statistik deskriptif dan analisis statistik inferensial. Menurut Supardi (2016:3) statistik deskriptif merupakan "bagian dari statistik yang mempelajari cara pengumpulan data dan penyajian data sehingga mudah dipahami". Lebih lanjut dinyatakan bahwa "statistik deskriptif adalah statistik yang berfungsi untuk mendeskripsikan atau memberi gambaran terhadap obyek yang diteliti melalui data sampel atau populasi sebagaimana adanya, tanpa melakukan analisis dan membuat kesimpulan yang berlaku untuk umum" (Sugiyono, 2009:29). Berdasarkan dua pendapat tersebut dapat dirangkum bahwa statistik deskriptif merupakan metode statistik yang mempelajari cara pengumpulan dan penyajian data untuk mendeskripsikan obyek yang diteliti tanpa melakukan analisis dan membuat kesimpulan yang berlaku untuk umum. Teknik analisis deskriptif dalam penelitian ini bertujuan untuk mendeskripsikan data kompetensi pengetahuan IPS siswa kelompok eksperimen dan kompetensi pengetahuan IPS siswa kelompok kontrol. Pada statistik deskriptif ini data kompetensi pengetahuan IPS siswa kelompok eksperimen dan kelompok kontrol disajikan untuk mengetahui nilai rata-rata (mean), nilai dengan frekuensi tertinggi (modus), nilai tengah (median), standar deviasi, dan varians.

Analisis statistik inferensial merupakan statistik yang dipakai untuk melakukan analisis data dengan cara membuat kesimpulan yang berlaku secara umum. "Analisis statistik inferensial adalah cara pengolahan data yang dilakukan dengan jalan menerapkan rumus-rumus statistik inferensial untuk menguji suatu hipotesis penelitian yang diajukan peneliti dan kesimpulan ditarik berdasarkan pengujian terhadap hipotesis" (Agung, 2014:110). Supardi (2016) menyatakan statistik inferensial adalah "bagian dari statistik yang mempelajari mengenai penafsiran dan penarikan kesimpulan yang berlaku secara umum dari data sampel yang tersedia. Jadi, dapat di rangkum bahwa metode analisis statistik inferensial 
adalah cara pengolahan data untuk melakukan penafsiran atau penarikan kesimpulan dari data sampel yang akan diberlakukan secara umum.

Pada penelitian ini, sebelum dilaksanakan pengujian hipotesis terlebih dahulu dilakukan uji prasyarat analisis dengan uji normalitas dan uji homogenitas. Uji normalitas sebaran data dalam penelitian ini menggunakan rumus Chi Kuadrat (x2) dengan kriteria x2hitung $<$ x2 tabel, maka data berdistribusi normal pada taraf signifikan $5 \%(\mathrm{dk}=\mathrm{k}-1)$. Uji homogenitas varians dilakukan dengan uji F, dengan kriteria pengujian, jika Fhitung < Ftabel maka sampel homogen. Pengujian dilakukan pada taraf signifikan 5\% dengan derajat kebebasan untuk pembilang n1-1 dan derajat kebebasan untuk penyebut n2-1.

Jika data yang diperoleh sudah memenuhi prasyarat uji normalitas dan homogenitas maka analisis data yang digunakan adalah analisis statistik parametrik. Analisis statistik yang digunakan untuk menguji hipotesis penelitian ini adalah uji-t dengan rumus polled varians. Dengan kriteria jika nilai thitung $\leq$ ttabel, maka Ho yang berbunyi tidak terdapat perbedaan yang signifikan kompetensi pengetahuan IPS antara kelompok siswa yang dibelajarkan dengan model Project Based Learning berbantuan media animasi dengan kelompok siswa yang dibelajarkan dengan model pembelajaran konvensional pada siswa kelas V SD Gugus 5 Mengwi tahun pelajaran 2017/2018 diterima dan Ha ditolak, dan jika nilai thitung > tabel maka Ho ditolak dan Ha diterima. Pengujian dilakukan pada taraf signifikan $5 \%$ dengan $\mathrm{dk}=\mathrm{n} 1+\mathrm{n} 2$ -2 .

\section{ANALISIS DAN PEMBAHASAN}

Hasil analisis statistik deskriptif data kompetensi pengetahuan IPS siswa kelompok eksperimen, terdapat 42 orang siswa dengan nilai tertinggi yang diperoleh siswa adalah 97 dan nilai terendah adalah 67. Dari sebaran data tersebut diperoleh rata-rata (mean) $=82,24$, median $=82,20$, dan modus $=82,20$. Varians data kompetensi pengetahuan IPS siswa kelompok eksperimen adalah 56,04 dengan standar deviasi 7,49. Data kompetensi pengetahuan IPS siswa kelompok eksperimen disajikan dalam histogram berikut.

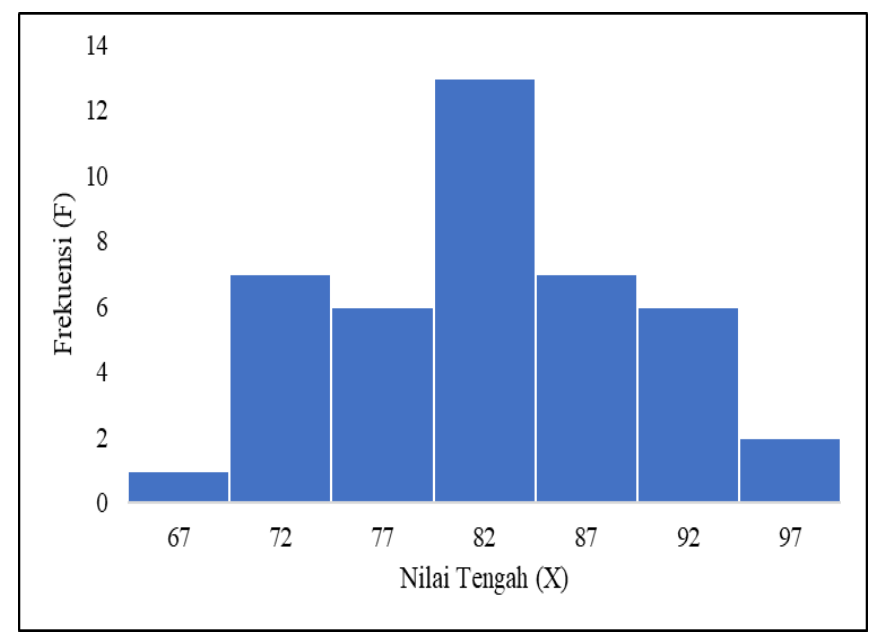

Gambar 1. Grafik Histogram Data Kompetensi Pengetahuan IPS Siswa Kelompok Eksperimen

Berdasarkan grafik histogram dan hasil analisis dapat dideskripsikan bahwa sebaran data nilai siswa pada kelas eksperimen terbagi ke dalam tujuh kelas interval dengan frekuensi tertinggi sebanyak 13 berada pada kelas interval dengan nilai titik tengah 82. Sedangkan frekuensi terendah sebanyak 1 berada pada kelas interval dengan titik tengah 67. Lebih lanjut terdapat dua kelas interval dengan titik tengah 72 dan 87 yang memiliki frekuensi sebanyak 7, dua kelas interval dengan titik tengah 77 dan 92 yang memiliki frekuensi sebanyak 6, dan satu kelas interval dengan titik tengah 97 memiliki frekuensi 2 . Selanjutnya dapat pula di deskripsikan bahwa nilai rata-rata (mean) $=82,24$, median dan modus $=82,19$ ketiganya berada pada kelas interval $80-84$ dengan frekuensi $=13$.

Hasil analisis statistik deskriptif data kompetensi pengetahuan IPS siswa kelompok kontrol, terdapat 37 orang siswa dengan nilai tertinggi yang diperoleh siswa adalah 83 dan nilai terendah adalah 60. Dari sebaran data tersebut diperoleh rata-rata (mean) $=72,53$, median $=72,50$, dan modus $=69,90$. Varians data kompetensi pengetahuan IPS siswa kelompok kontrol adalah 43,03 dengan standar deviasi 6,56. Data kompetensi pengetahuan IPS siswa kelompok kontrol disajikan dalam histogram berikut. 


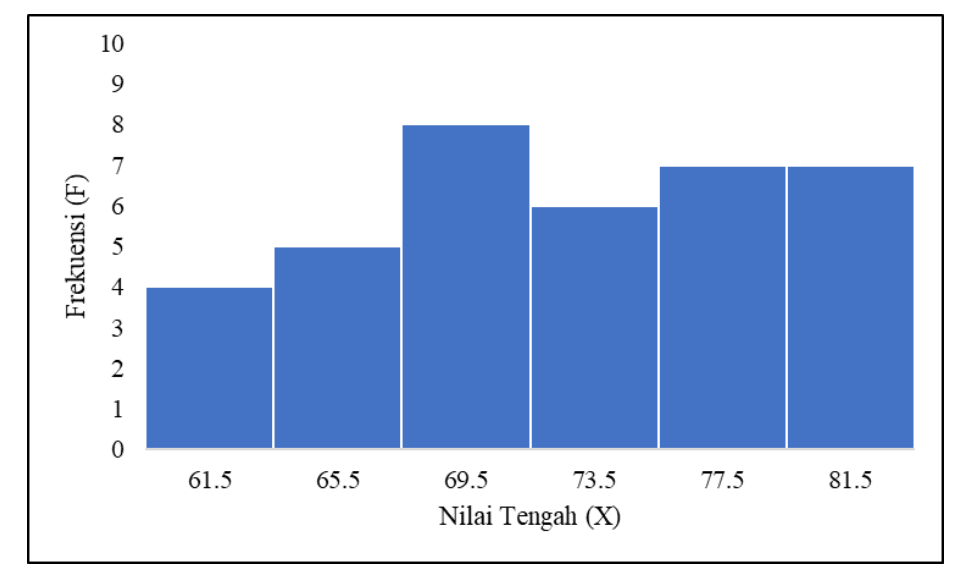

Gambar 2. Grafik Histogram Data Kompetensi Pengetahuan IPS Siswa Kelompok Kontrol

Berdasarkan grafik histogram dan analisis data dapat dideskripsikan bahwa sebaran data nilai siswa pada kelas kontrol terbagi ke dalam 6 kelas interval dengan frekuensi tertinggi sebanyak 8 berada pada kelas interval dengan nilai titik tengah 69,5. Sedangkan frekuensi terendah sebanyak 4 berada pada kelas interval dengan titik tengah 61,5 . Lebih lanjut terdapat dua kelas interval dengan titik tengah 77,5 dan 81,5 yang memiliki frekuensi sebanyak 7 , satu kelas interval dengan titik tengah 73,5 memiliki frekuensi sebanyak 6, dan satu kelas interval dengan titik tengah 65,5 memiliki frekuensi 5 . Selanjutnya dapat pula dideskripsikan bahwa nilai rata-rata $($ mean $)=72,53$, dan median $=72,50$ berada pada kelas ininterval $70-75$, modus $=69,90$ berada pada kelas interval $68-71$.

Sebelum dilaksanakan pengujian hipotesis terlebih dahulu dilakukan uji prasyarat analisis dengan uji normalitas dan uji homogenitas. Uji normalitas sebaran data dimaksudkan untuk mengetahui sebaran data berdistribusi normal atau tidak. Berdasarkan perhitungan uji normalitas data kompetensi pengetahuan IPS siswa kelompok eksperimen diperoleh nilai $\mathrm{x}^{2}$ hitung $=2,078$ sedangkan untuk taraf signifikan $5 \%$ dan derajat kebebasan $(\mathrm{dk})=5$ diperoleh $\mathrm{x}^{2}{ }_{\text {tabel }}=11,070$. Karena $\mathrm{x}^{2}$ hitung $=2,078<\mathrm{x}^{2}$ tabel $=$ 11,070 maka $\mathrm{H}_{0}$ diterima, sehingga data kompetensi pengetahuan IPS siswa kelompok eksperimen berdistribusi normal.

Berdasarkan perhitungan uji normalitas data kompetensi pengetahuan IPS siswa kelompok kontrol diperoleh nilai $\mathrm{x}^{2}$ hitung $=2,416$ sedangkan untuk taraf signifikan $5 \%$ dan derajat kebebasan $(\mathrm{dk})=5$ diperoleh $\mathrm{x}^{2}$ tabel $=11,070$. Karena $\mathrm{x}^{2}$ hitung $=2,416<\mathrm{x}^{2}$ tabel $=11,070$ maka $\mathrm{H}_{0}$ diterima, sehingga data kompetensi pengetahuan IPS siswa kelompok kontrol berdistribusi normal.

Pengujian homogenitas varians antar kelompok dimaksudkan untuk meyakinkan bahwa perbedaan yang diperoleh dalam uji-t benar-benar berasal dari perbedaan antar kelompok bukan disebabkan oleh perbedaan di dalam kelompok. Dari hasil perhitungan diperoleh $F_{\text {hitung }}=1,30$, hasil ini kemudian dibandingkan dengan harga $\mathrm{F}_{\text {tabel }}$ dengan derajat kebebasan pembilang 42-1 = 41 dan derajat kebebasan penyebut 37-1 = 36 dengan taraf signifikan 5\%, sehingga diperoleh $F_{\text {tabel }}=1,72$. Karena harga $F_{\text {hitung }}<F_{\text {tabel }}$ $(1,30<1,72)$, maka varians data kompetensi pengetahuan IPS antara siswa kelompok eksperimen dan kelompok kontrol adalah homogen.

Dari hasil uji prasyarat yaitu uji normalitas dan homogenitas diperoleh hasil yaitu data kompetensi pengetahuan IPS dari kelompok eksperimen dan kelompok kontrol berdistribusi normal dan homogen. Berdasarkan hal tersebut, dapat dilanjutkan dengan menguji hipotesis dengan rumus uji-t polled varians. Adapun hipotesis yang diuji dalam penelitian ini adalah hipotesis nol $\left(\mathrm{H}_{0}\right)$ yang berbunyi tidak terdapat perbedaan yang signifikan kompetensi pengetahuan IPS antara kelompok siswa yang dibelajarkan dengan model Project Based Learning berbantuan media animasi dengan kelompok siswa yang dibelajarkan dengan model pembelajaran konvensional pada siswa kelas V SD Gugus 5 Mengwi tahun pelajaran $2017 / 2018$.

Dari hasil perhitungan diperoleh $t_{\text {hitung }}$ sebesar 6,146 sedangkan nilai $t_{\text {tabel }}$ pada taraf signifikan $5 \%$ dengan derajat kebebasan $(\mathrm{dk}=42+37-2=77)$ adalah 2,000. Karena $t_{\text {hitung }}>t_{\text {tabel }}(6,146>2,000)$ maka $\mathrm{H}_{0}$ yang berbunyi tidak terdapat perbedaan yang signifikan kompetensi pengetahuan IPS antara kelompok siswa yang dibelajarkan dengan model Project Based Learning berbantuan media animasi dengan kelompok siswa yang dibelajarkan dengan model pembelajaran konvensional pada siswa kelas V SD Gugus 5 Mengwi tahun pelajaran 2017/2018 ditolak dan $\mathrm{H}_{\mathrm{a}}$ yang berbunyi terdapat terdapat perbedaan yang signifikan kompetensi pengetahuan IPS antara kelompok siswa yang dibelajarkan dengan model Project Based Learning berbantuan media animasi dengan kelompok siswa yang dibelajarkan dengan 
model pembelajaran konvensional pada siswa kelas V SD Gugus 5 Mengwi tahun pelajaran 2017/2018 diterima. Dengan demikian, model Project Based Learning berbantuan media animasi berpengaruh terhadap kompetensi pengetahuan IPS siswa kelas V SD Gugus 5 Mengwi tahun pelajaran 2017/2018.

Berdasarkan hasil penelitian yang diperoleh bahwa terdapat pengaruh model Project Based Learning berbantuan media animasi terhadap kompetensi pengetahuan IPS siswa kelas V SD Gugus 5 Mengwi tahun pelajaran 2017/2018, yang ditunjukkan dengan $t_{\text {hitung }}>t_{\text {tabel }}(6,146>2,000)$ dengan taraf signifikansi 5\% dan derajat kebebasan 77.

Perolehan hasil perhitungan analisis data yang dilakukan menunjukkan bahwa nilai rata-rata siswa yang dibelajarkan dengan menggunakan model Project Based Learning berbantuan media animasi ( $\bar{X}=$ $82,24)$ dan siswa yang dibelajarkan dengan pembelajaran konvensional $(\bar{X}=72,53)$ memiliki perbedaan sebesar 9,71. Berdasarkan hasil temuan tersebut, dapat dinyatakan bahwa kedua kelompok sampel penelitian awalnya memiliki kemampuan setara, setelah diberikan perlakuan berupa pembelajaran dengan menggunakan model Project Based Learning berbantuan media animasi pada kelompok eksperimen dan mengikuti pembelajaran menggunakan pendekatan saintifik pada kelompok kontrol diperoleh hasil kompetensi pengetahuan IPS yang berbeda. Hal ini dapat dilihat dari $\bar{X}$ siswa yang mengikuti pembelajaran menggunakan model Project Based Learning berbantuan media animasi lebih tinggi dibandingkan dengan $\bar{X}$ siswa yang mengikuti pembelajaran konvensional, dalam hal ini adalah pembelajaran yang menggunakan pendekatan saintifik. Perbedaan rata-rata kompetensi pengetahuan IPS siswa pada kelompok eksperimen dan kelompok kontrol tersebut disebabkan karena pembelajaran dengan menerapkan model Project Based Learning pada kelompok eksperimen.

Pembelajaran dengan menerapkan model Project Based Learning memberikan kesempatan yang lebih banyak kepada siswa untuk mengkonstruksi atau membentuk pemahamannya sendiri terhadap konsep pelajaran dengan membuat suatu produk atau karya. Dalam pembuatan karya tersebut, kolaborasi antara pemahaman (pengetahuan) dan keterampilan siswa memiliki porsi yang relatif berimbang sehingga penerapan model Project Based Learning berbantuan media animasi tidak hanya dapat dirasakan oleh siswa yang pandai dalam segi kognitif saja tetapi juga siswa yang lemah dalam segi kognitif tetapi memiliki keterampilan untuk membuat karya.

Anak usia sekolah dasar dalam perkembangannya berada dalam tahap operasional konkret sehingga pembelajaran yang dilaksanakan oleh anak memerlukan media yang dapat menggambarkan materi pembelajaran secara nyata. Anak tidak mampu berimajinasi kepada suatu hal-hal yang tidak pernah mereka lihat atau alami sebelumnya. Media animasi yang diterapkan dalam model Project Based Learning sangat membantu siswa dalam memvisualisasikan atau menggambarkan peristiwa-peristiwa sejarah dalam materi muatan pelajaran IPS, sehingga dapat membantu imajinasi dan pemahaman siswa dalam merencanakan proyek yang mereka buat. Hal tersebut sejalan dengan pendapat Susanto (2014) yang menyatakan salah satu kelebihan penggunaan media animasi adalah untuk menghilangkan hambatan intelektual dalam memahami suatu konsep. Melalui penggunaan media animasi ini, siswa merasa lebih mudah untuk memahami konsep materi sejarah yang bersifat abstrak.

Dalam pembuatan proyek, siswa terlibat aktif dalam perencanaan dan kerjasama dalam kelompok. Siswa diberikan kesempatan secara aktif untuk menuangkan ide-ide yang mereka punya dalam sebuah karya yang menarik. Guru berperan sebagai fasilitator siswa, sehingga pembelajaran berpusat pada siswa (student center). Siswa lebih antusias dalam membuat hal-hal baru yang belum pernah mereka kerjakan, sehingga lebih mengundang rasa ingin tahu siswa dan dapat lebih memotivasi siswa dalam belajar.

Usia anak sekolah dasar tidak hanya harus dibebani materi-materi yang sifatnya teoretis saja. Pengajaran perlu disisipkan hal-hal tertentu yang dapat merangsang pikiran siswa agar materi yang diajarkan dapat menarik bagi siswa. Dalam hal ini pembelajaran model Project Based Learning berbantuan media animasi mempunyai peranan yang tepat untuk membangkitkan motivasi serta menanamkan pengetahuan secara efektif melalui pembuatan suatu produk atau karya. Pembelajaran Project Based Learning ini mengajak siswa untuk berlatih merencanakan sesuatu, mengolah sumber belajar, dan memutuskan suatu hal melalui kerjasama dalam kelompok. Hal tersebut dapat membentuk karakter siswa dalam bekerjasama dengan kelompok sehingga pembelajaran lebih bermakna.

Hasil penelitian ini memperkuat simpulan yang disampaikan oleh Andana (2014) yang menyatakan bahwa model pembelajaran berbasis proyek berpengaruh terhadap hasil belajar IPA siswa kelas IV SD di Gugus V Kecamatan Tegallalang Kabupaten Gianyar pada Semester Ganjil Tahun Pelajaran 2013/2014. Dengan demikian, dapat dikatakan bahwa model Project Based Learning berbantuan media animasi berpengaruh signifikan terhadap penguasaan kompetensi pengetahuan IPS siswa kelas V SD Gugus 5 Mengwi Tahun Pelajaran 2017/2018. 


\section{KESIMPULAN}

Berdasarkan hasil analisis data kompetensi pengetahuan IPS sampel diperoleh hasil thitung $=6,146$ sedangkan nilai ttabel pada taraf signifikansi 5\% dengan derajat kebebasan ( $\mathrm{dk}=42+37-2=77)$ adalah 2,000 . Karena thitung $>$ ttabel $(6,146>2,000)$ maka H0 yang berbunyi tidak terdapat perbedaan yang signifikan kompetensi pengetahuan IPS antara kelompok siswa yang dibelajarkan dengan model Project Based Learning berbantuan media animasi dengan kelompok siswa yang dibelajarkan dengan model pembelajaran konvensional pada siswa kelas V SD Gugus 5 Mengwi tahun pelajaran 2017/2018 ditolak dan Ha yang berbunyi terdapat perbedaan yang signifikan kompetensi pengetahuan IPS antara kelompok siswa yang dibelajarkan dengan model Project Based Learning berbantuan media animasi dengan kelompok siswa yang dibelajarkan dengan model pembelajaran konvensional pada siswa kelas V SD Gugus 5 Mengwi tahun pelajaran 2017/2018 diterima. Rata-rata kompetensi pengetahuan IPS siswa yang dibelajarkan dengan model Project Based Learning berbantuan media animasi adaah 82,24 dan siswa yang mengikuti pembelajaran konvensional yaitu 72,53 memiliki perbedaan sebesar 9,71. Jadi, dapat disimpulkan bahwa terdapat pengaruh model Project Based Learning berbantuan media animasi terhadap kompetensi pengetahuan IPS siswa kelas V SD Gugus 5 Mengwi tahun pelajaran 2017/2018.

Berdasarkan temuan penelitian yang diperoleh, disarankan kepada guru agar lebih kreatif untuk memberikan variasi dalam pembelajaran, sumber belajar dan kesempatan yang lebih besar bagi siswa pada pembelajaran dengan menggunakan model Project Based Learning berbantuan media animasi sehingga tercipta pembelajaran yang lebih bermakna dan menyenangkan bagi siswa. Sekolah hendaknya memfasilitasi terlaksananya model Project Based Learning berbantuan media animasi agar siswa semakin termotivasi untuk belajar dan memanfaatkan fasilitas tersebut untuk mengoptimalkan hasil belajar siswa sehingga mutu sekolah menjadi meningkat. Kepada peneliti lain hendaknya hasil penelitian ini dapat dijadikan kajian penelitian relevan. Sebagai penunjang penelitian dengan kajian yang lebih luas dan mendalam mengenai model Project Based Learning berbantuan media animasi dalam kaitannya dengan hasil belajar baik kompetensi pengetahuan, sikap, maupun keterampilan.

\section{DAFTAR PUSTAKA}

Aditya, I Km. Ngurah Budi (2014). “Pembelajaran Berbasis Komunikatif Berbantuan Media Animasi Berpengaruh Terhadap Hasil Belajar Matematika Siswa Kelas V SD Negeri Gugus V Kecamatan Karangasem". Jurnal Mimbar PGSD Universitas Pendidikan Ganesha, Volume 2, Nomor 1. Tersedia pada http://id. portalgaruda.org/index.php?ref=browse\&mod=viewarticle \&article=138762 (diakses tanggal 10 Januari 2018).

Agung. A.A. Gede. 2014. Buku Ajar Metodologi Penelitian Pendidikan. Malang: Aditya Media Publishing.

Al-Tabany, Trianto Ibnu Badar. 2015. Mendesain Model Pembelajaran Inovatif, Progresif, dan Kontekstual: Konsep, Landasan, dan Implementasinya pada Kurikulum 2013 (Kurikulum Tematik Integratif/TKI). Jakarta: Prenadamedia Group.

Andana, I Md. Edi (2014). "Pengaruh Model Pembelajaran Berbasis Proyek Terhadap Hasil Belajar IPA Siswa Kelas IV SD di Gugus V Kecamatan Tegallalang”. Jurnal Mimbar PGSD Universitas Pendidikan Ganesha, Volume 2, Nomor 1. Tersedia pada http://id.portalgaruda.org/?ref=browse\& mod=viewarticle\&article=145719 (diakses tanggal 10 Januari 2018).

Arsyad, Azhar. 2017. Media Pembelajaran. Jakarta: Rajawali Pers.

Dantes, N. 2012. Metode Penelitian. Yogyakarta: Andi Yogyakarta.

Daryanto, dkk. 2014. Siap Menyongsong Kurikulum 2013. Yogyakarta: Gava Media.

Gunawan, Rudy. 2016. Pendidikan IPS Filosofi, Konsep, dan Aplikasi. Bandung: Alfabeta.

Kurniawati , Ivatul Laily dan Dhamas Mega Amarlita. 2013. “Pengembangan Bahan Ajar Berbasis Masalah Pada Mata Pelajaran Kimia SMA Kelas X Dalam Materi Hidrokarbon”. Jurnal Pendidikan Kimia Vol 3 No 22013 78-90. 
Mahendra, I Wayan Eka.2017. Project Based Learning Bermuatan Etno Matematika dalam Pembelajar Matematika. Jurnal Pendidikan Indonesia Vol. 6, No.1, April 2017 106-114.

Natalia. 2017. Penerapan Model Pembelajaran Berbasis Masalah Dengan Bantuan Media Video untuk Meningkatkan Keterampilan Menulis Teks Eksposisi Siswa. Jurnal Penelitian dan Pengembangan Pendidikan Vol. 1 (2) pp. 75-81.

Permendikbud Nomor 57 Tahun 2014 tentang Kurikulum 2013 Sekolah Dasar/ Madrasah Ibtidaiyah, 2014. Jakarta: Departemen Pendidikan dan Kebudayaan.

Permendikbud Nomor 22 Tahun 2016 tentang Standar Proses Pendidikan Dasar dan Menengah, 2016. Jakarta: Departemen Pendidikan dan Kebudayaan.

Permendikbud Nomor 24 Tahun 2016 tentang Kompetensi Inti dan Kompetensi Dasar Pelajaran Dalam Kurikulum 2013 Pada Pendidikan Dasar dan Pendidikan Menengah, 2016. Jakarta: Departemen Pendidikan dan Kebudayaan.

Ram, Preeta. 1999. Problem-based Learning in Undergraduate Education: a Sophomore Chemistry Laboratory, Journal of Chemical Education, (online), vol. 76, No 8 (http://www.JchemEd.chem.wisc.edu).

Satria, Ketut \& Made Windu Antara Kesima, I Gede Mahendra Darmawiguna. 2013. "Pengembangan Media Audio-Visual Pada Mata Diklat Menerapkan Efek Khusus Pada Objek Produksi Berbasis Project Based Learning Untuk Siswa Kelas XII SMK Negeri 3 Singaraja". Jurnal Nasional Pendidikan Teknik Informatika (JANAPATI) Volume 2, Nomor 1, Maret 2013 hal 1-16.

Sugiyono. 2009. Metode Penelitian Pendidikan Pendekatan Kuantitatif, Kualitatif dan R\&D. Bandung: Alfabeta.

Supardi, U.S. 2016. Aplikasi Statistika Dalam Penelitian. Jakarta: Change Publication.

Susanto, Ahmad. 2014. Pengembangan Pembelajaran IPS di Sekolah Dasar. Jakarta: Prenadamedia Group.

Wahidmurni, H. 2017. Metodologi Pembelajaran IPS. Yogyakarta: Ar-Ruzz Media.

Udayana, Ngurah Nyoman Arya dan I Made Agus Wirawan, Dewa Gede Hendra Divayana. 2017. Pengembangan E-Modul Pada Mata Pelajaran Pemrograman Berorientasi Objek Dengan Model Pembelajaran Project Based Learning Kelas XII Rekayasa Perangkat Lunak. Volume 6, Nomor 2, Juli 2017 hal 128-39.

Undang-undang Nomor 20 Tahun 2003 tentang Sistem Pendidikan Nasional, 2003. Jakarta: Departemen Pendidikan Nasional. 